\title{
The Norian Worthenia-like gastropods (Main Dolomite, Upper Triassic): reclassification of the specimens housed at the "Antonio Stoppani" Natural Museum, Italy
}

\author{
Vittorio Pieroni
}

\begin{abstract}
Despite being very common, the Norian gastropods of the Main Dolomite Formation usually referred to as "Worthenia", have not been well classified yet. This is principally due to a dearth of well-preserved specimens. Moreover, the type material of the species instituted by Stoppani has not been re-examined in recent publications. Therefore, a thorough search for the Stoppani Collection's reference types in the storerooms of the Museo di Storia Naturale di Milano has been carried out. This investigation revealed that the gastropod types from Main Dolomite described by Stoppani had effectively been lost, possibly following an air-bombing raid hitting the museum during World War II. Consequently, we here describe only two specimens from the portion of the Stoppani Collection housed at the Museo Scientifico Naturalistico “A. Stoppani”, Venegono Inferiore (Varese, Italy). These two specimens were collected by Antonio Stoppani in Songavazzo (Bergamo, Italy) that he himself identified as one of the type localities. These particularly well-preserved specimens display characters useful for their possible attribution to the genus Wortheniella.
\end{abstract} pani.

Key words: gastropods, Worthenia, Norian, Main Dolomite, Stop-

Riassunto - I gasteropodi norici Worthenia s. 1. (Dolomia Principale, Triassico Superiore): riclassificazione degli esemplari custoditi nel Museo Naturale "Antonio Stoppani”, Italia.

Nonostante siano molto comuni, i gasteropodi norici della Dolomia Principale di solito considerati come "Worthenia", non sono stati ancora ben classificati. Ciò è dovuto principalmente alla mancanza di esemplari ben conservati. Inoltre, il materiale tipico delle specie istituite da Stoppani non è stato riesaminato in pubblicazioni recenti. Pertanto, è stata effettuata una ricerca approfondita dei tipi di riferimento della collezione Stoppani nei magazzini del Museo di Storia Naturale di Milano. Questa indagine ha rivelato che i tipi di gasteropodi della Dolomia Principale descritti da Stoppani erano stati effettivamente persi, probabilmente in seguito al bombardamento aereo che colpì il museo durante la seconda guerra mondiale. Di conseguenza, qui descriviamo solo due esemplari della porzione della Collezione Stoppani conservata presso il Museo Scientifico Naturalistico “A. Stoppani “, Venegono Inferiore (Varese, Italia). Questi due esemplari furono raccolti da Antonio Stoppani a Songavazzo (Bergamo, Italia) che egli stesso identificò come una delle località tipo. Questi esemplari particolarmente ben conservati mostrano caratteri utili per la loro possibile attribuzione al genere Wortheniella.

Museo Scientifico Naturalistico “Antonio Stoppani”, Seminario Arcivescovile "Pio XI", Via Papa Pio XI, 32, 21040 Venegono Inferiore (VA), Italia.

E-mail: info@marianopieroni.it

\section{(C) 2019 Vittorio Pieroni}

Received: 31 May 2018

Accepted for publication: 16 January 2019

Online publication: 18 March 2019
Parole chiave: gasteropodi, Worthenia, Norico, Dolomia Principale, Stoppani.

\section{INTRODUCTION}

Classification of the typical gastropods from Main Dolomite (Norian, Upper Triassic, Italy and some south European localities) - which have been known since the 1800 s (Stoppani, 1860-65; Costa, 1864) and commonly referred to as Worthenia s. 1. - has long been problematic on account of the poor preservation of most of the finds and the particular history of the reference collections. This problem has been tackled on more than one occasion in the literature (e.g. Tommasi, 1903; Haas, 1953; Tichy, 1975), but now tends to be further complicated by the modern criteria of classification that are based mainly on the larval shell and on the early teleoconch, which is often difficult to observe on strongly recrystallized shells. Indeed, the degree of preservation of gastropods from Main Dolomite is usually mediocre. The specimens consist of impression fossils covered by crystals with partially and badly preserved internal moulds. Pseudoshells with traces of growth lines are found only rarely.

\section{THE HISTORICAL COLLECTIONS}

The Worthenia s. 1. types from Main Dolomite in Lombardy and near Salerno in Campania (Monti Picentini, Giffoni Valle Piana) were lost during World War II. The specimens coming from Campania (comprising those of Costa Collection) were kept at the Museo di Paleontologia di Napoli, which was badly damaged by an incendiary bomb in 1941. Very few materials remain from the collections of Upper Triassic gastropods accredited to the studies of Antonio Stoppani, who had erected the species found in Lombardy. A thorough search for this material was conducted by this author (VP) and by Dr Giorgio Teruzzi, curator at the Museo di Storia Naturale di Milano (last search carried out on 11 January 2018). Most of the collections kept in that museum - which also housed the entire Stoppani Collection prior to WWII - were destroyed by the bombardments. As far as the material from the Norian Main Dolomite published by Stoppani is concerned, only some remains of megalodontid bivalves (Teruzzi, 2015), are still present. Tommasi (1903) was the only author who redescribed these species after being able to view the holotypes or the often-fragmentary speci- 
mens used by Stoppani to prepare his original illustrations and descriptions.

Other than the Triassic material of Stoppani Collection still stored at the Museo di Storia Naturale di Milano (Garassino, 1992; Teruzzi, 2015; Pieroni, 2016), several specimens are housed at the Museo Scientifico Naturalistico "A. Stoppani", Seminario Arcivescovile Pio XI, Venegono Inferiore (VA), Italy (Gentili \& Pieroni, 2011; Pieroni, 2014). Specifically, within the portion of the Stoppani Collection kept at the latter museum, numerous fragments of bivalves (Neomegalodon; Isocardia?) and gastropods ("Worthenia" s. 1.; Purpuroidea?), coming from the Main Dolomite of the classical sites of Songavazzo (BG) and Val Sarezzo (BS), Italy, have been identified. Two gastropods belonging to the Worthenia $\mathrm{s}$. 1. group display characters only rarely observed up to now, which can be profitably utilized to identify the genus to which these forms belong.

Subclass ORTHOGASTROPODA Ponder \& Lindberg, 1996 Superorder VETIGASTROPODA Salvini-Plawen, 1980

Superfamily Eotomarioidea Wenz, 1938

Family Wortheniellidae Bandel, 2009

Genus Wortheniella Schwardt 1992

Type species: Worthenia coralliophila Kittl, 1891

Wortheniella pygmaea (Stoppani, 1860-65) Comb. nov. (Fig. 1A-F)

1860-65 Delphinula pygmaea Stoppani, p. 256-57, pl. 59, fig. 16-17

1860-65 Delphinula regazzoni Stoppani, p. 257, pl. 59, fig. 18

1903 Worthenia pygmaea (Stoppani) - Tommasi, p. 114 [20], pl. 18 [3], fig. 14a-e

Holotype: The holotypes of Delphinula pygmaea and Delphinula regazzoni, like the rest of the specimens from Main Dolomite published by Stoppani in Series III of "Paléontologie Lombarde", are lost (see above).

Locus typicus: Caino (near Brescia, BS), Italy.

Stratum typicum: Main Dolomite (Norian).

Material: Two specimens [catalogue numbers AS 41/43 (Fig. 1A-D) and AS 41/43a (Fig. 1E,F)], almost totally preserved as pseudoshells recrystallised in dolomite, from Songavazzo (BG), Italy. The specimens are part of the historic Stoppani Collection housed at the Museo Scientifico Naturalistico "Antonio Stoppani" in the Seminario Arcivescovile Pio XI, Diocese of Milan, Venegono Inferiore, Italy. Although not the typical site for the species, Songavazzo is one of the localities where Stoppani collected the Norian gastropods he described in "Paléontologie Lombarde".

Dimensions: AS 41/43: $\mathrm{H}=6.80 \mathrm{~mm} ; \mathrm{W}=7.45 \mathrm{~mm}$; $\mathrm{PA}=62^{\circ}$. AS 41/43a: $\mathrm{H}=10.60 \mathrm{~mm} ; \mathrm{W}=11.80 \mathrm{~mm} ; \mathrm{PA}=75^{\circ}$.

Description: Specimen AS 41/43 has a gradate trochiform shell consisting of just over 5 rapidly grown whorls. Adult whorls have an adapical and an abapical spiral carina. The former is at the angle between the ramp and the flank; the latter is at the angle between the flank and the base. The flank is flattened and almost perpendicular to the coil axis. The two early teleoconch whorls are rounded and lack evident ornamentation. The next three whorls have a distinct adapical carina. The abapical carina is exposed only on the last whorl, whereas it corresponds to the suture on the pre- ceding two whorls. The first preserved whorl is almost planispiral. The apical part is strongly recrystallized and thus the characters of the protoconch are not identifiable. A selenizone is present in correspondence with the robust adapical spiral carina separating the sutural ramp, which is inclined and slightly swollen, from the flank of the whorl at an obtuse angle. This carina is sculptured with well-spaced, longitudinally elongate nodules. The abapical carina, thinner than the former, does not have evident nodules. The whole surface of the shell is sculptured with more or less fine threads crossed by growth lines. Three threads are visible on the sutural ramp, of which the two adapical ones are significantly more pronounced and closer together, whereas the abapical one is thinner and located further away from the two adapical threads and from the adapical carina. Three threads are present also on the flank. They are more or less equidistant between the two carinae and well developed. The base, which for the most part is embedded in matrix, is weakly rounded, convex and sculptured with more than five evident threads. The growth lines are prosocline and prosocyrt on the ramp, prosocyrt on the flank below the selenizone, prosocline on the base. The aperture, distinctly wider than high, is polygonal in shape being angulated at the two spiral carinae. The specimen AS 41/43a - which has been completely extracted from the matrix, but has an eroded pseudoshell - shows a quite well developed columellar lip that covers almost completely the rather small umbilicus. Evident threads are visible on the base of this specimen, too.

Discussion: This species is described by Stoppani (186065) from Norian Main Dolomite of Caino (BS). In the fauna from some Prealpine Lombard localities in the provinces of Bergamo and Brescia, Stoppani described Turbo songavatii Stoppani, 1860-65 (=Turbo solitarius Benecke, 1866, which according to De Stefani 1880 was a junior synonym of Turbo songavatii, which Haas 1953 considered a synonym of Trochus contabulatus Costa, 1864, p. 232, pl. 5, fig. 4), Turbo pusillus Stoppani, 1860-65, Pleurotomaria inzini Stoppani, 1860-65, Delphinula escheri Stoppani, 1860-65, Delphinula diadema Stoppani, 1860-65, Delphinula regazzoni Stoppani, 1860-65, Delphinula meriani Stoppani, 1860-65, and Delphinula inzini Stoppani, 1860-65. In the same publication, he described a species from the Rhaetian of Lombardy - Neritopsis? oldae Stoppani, 1860-65 - which was closely related to the former.

In the revision proposed by Tommasi (1903) who compared Stoppani's types with new material collected specifically in the type locality (specimens housed at the Museo di Storia Naturale dell'Università di Pavia), all these forms were redescribed with the following generic designations: Worthenia songavatii, Worthenia pusilla, Worthenia inzini, Worthenia pygmaea, Worthenia meriani, Worthenia sp., and the new species Worthenia stoppanii. Delphinula escheri and Delphinula diadema were tentatively attributed to the genus Schizogonium Koken, 1889, considering possible attribution also to the genus Guidonia De Stefani, 1880. This distinction regarding the genera Delphinula escheri and Delphinula diadema is questionable: the specimens described in Tommasi 1903 display great uniformity in their main characters, so should have been attributed to a single genus. In particular, the six specimens classified as Schizogonium (?) escheri (cat. n. MSNP 20814) - the best preserved of which was illustrated by Tommasi in Table 3, Fig. 19 - do not display any sub- 


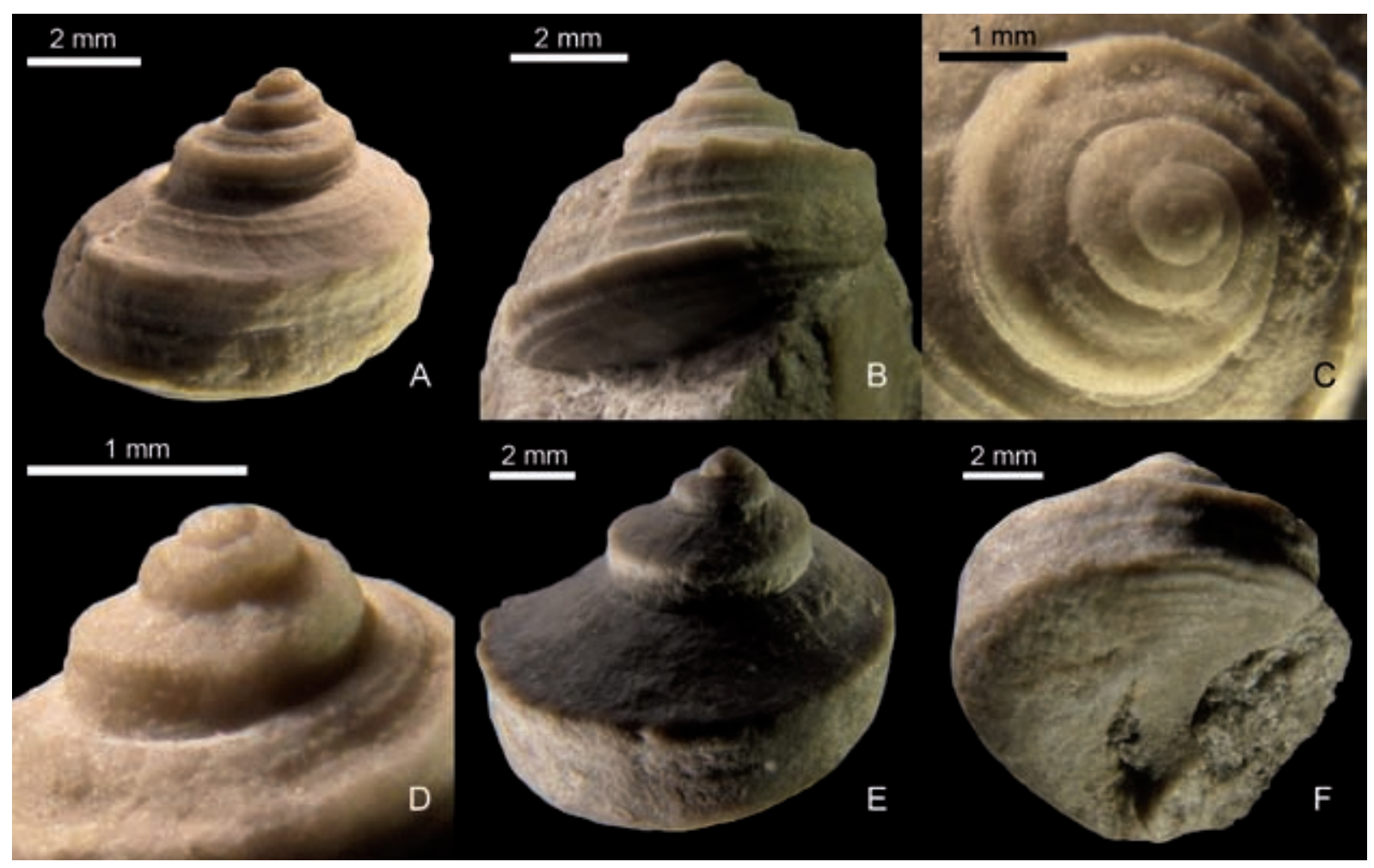

Fig. 1 - A) Wortheniella pygmaea (Stoppani) AS 41/43, lateral view, showing the pattern of the growth lines, which curve backwards above and below the nodose adapical carina (corresponding to the selenizone). Songavazzo (BG), Norian, Main Dolomite. B) Wortheniella pygmaea (Stoppani) AS 41/43, latero-basal view, showing the very conspicuous threads on the base. C) Wortheniella pygmaea (Stoppani) AS 41/43, apical view of the early whorls of the spire. D) Wortheniella pygmaea (Stoppani) AS 41/43, lateral view of the early whorls of the spire. E) Wortheniella pygmaea (Stoppani) AS 41/43a, lateral view. F) Wortheniella pygmaea (Stoppani) AS 41/43a, latero-basal view, showing the region of the umbilicus, which is largely occupied by a columellar lip.

stantial differences with the other forms attributed by him to the genus Worthenia. Indeed, the description of the growth lines and upper carina of Schizogonium (?) escheri made by Tommasi implicitly suggests the presence of a selenizone. The author considered Delphinula regazzoni synonym of $W$. pygmaea and deemed Stoppani's drawing of $D$. regazzoni to be based on a single, poorly preserved specimen that, in reality, is very similar to W. pygmaea. Even Worthenia meriani is very similar to $W$. pygmaea, but Tommasi thought $W$. meriani to be distinct in that, in contrast with the figure in Stoppani (1860-65), the holotype had a base that lacked ornamentation.

The general appearance of these Norian species is always the same, with ornaments that are more or less accentuated. Haas (1953) extensively discussed these forms (pp. 56-63), but he did not have access to Stoppani's or Costa's species type specimens of Trochus contabulatus Costa, 1864, and Worthenia contabulata, which had probably already been lost during WWII (p. 62). Not being able to study the types, Haas compared his Peruvian specimens with the material from Main Dolomite of Esztergár Valley, Hungary, illustrated by Kittl (1900). According to Haas, in that material the growth lines, which in the figures in Kittl (1900) suggest the presence of a selenizone, are in reality deformed and rather axial on the flanks indicating that the shell lacks a true selenizone. Haas attributed those forms to the genus Guidonia De Stefani, 1880 (family Trochonematidae), amending the diagnosis of Guidonia by identifying a type species (Trochus rotulus Stoliczka, 1861), because De Stefani formally did not indicate it (for a history of the genus see: Gatto \& Monari, 2010). In contrast, the specimens described here, like those in Tommasi (1903), display evidently prosocyrt growth lines on the sutural ramp and on the flank, with a marked edge in correspondence with the adapical carina, which is very much like the typical selenizone of Worthenia. The presence of a true selenizone was hypothesised also in Tichy (1975) on specimens of Worthenia contabulata from Main Dolomite from Austria. However, Tichy did not have well-preserved specimens at his disposal, so was not able to observe the growth lines.

Thus, giving as certain the attribution of these specimens to the "Worthenia group", these forms must be classified more precisely at the genus level. A possible solution derives from the study of the first whorls that appear fairly well preserved in AS 41/43. Research on the juvenile stages of the "Worthenia group" has brought to the designation of new genera that are rather similar in relation to their teleoconchs. As mentioned by Nuetzel \& Senowbari-Darian (1999), Chronic (1952) erected the genus Platyworthenia for some Permian US forms that differ from Worthenia Koninck, 1883 in having very low early whorls. Subsequently, Knight et al. (1960, p. I209) considered Platyworthenia and Worthenia as synonyms, on account of their great similarity. Later Yoo (1994) illustrated the protoconch and the first teleoconch whorls of the Carboniferous specimens attributed by him to Worthenia demonstrating that the early shell is trochiform. Schwardt (1992) erected the genus Wortheniella for specimens of the Upper Triassic St. Cassian Formation characterised by plani- 
spiral juvenile whorls. Nuetzel \& Senowbari-Darian (1999, p. 97) assigned the Norian species from the Iranian Nayband Formation to the genus Wortheniella, and discussed the differences between the genera Worthenia De Koninck, 1883, Wortheniella Schwardt, 1992 and Platyworthenia Chronic, 1952, which are certainly related to each other. They concluded that this distinction depends upon the importance one wants to bestow upon the morphology of first teleoconch whorls. Conversely, Nuetzel \& Erwin (2004) assigned the species of this group from the Norian deposits of Idaho (U.S.A.) to Worthenia. Finally, Bandel (2009, p. 17) erected the family Wortheniellidae, describing the protoconchs of the Carnian forms from the St. Cassian Formation as sinistral and situated a little under the first whorl of the teleoconch.

\section{CONCLUSIONS}

The specimens here described cannot be ascribed to the genus Guidonia: indeed, their growth lines not only differ from those of Guidonia, but also contribute to demonstrate the presence of a selenizone. Hypothetically, the Carboniferous forms having trochiform protoconchs and early teleoconch (Worthenia) gave rise in the Permian to forms with lower early whorls (Platyworthenia) and in the Triassic to forms with a planispiral to sinistral protoconch embedded in the first whorl (Wortheniella). Despite the lack of an observable protoconch, the genus Wortheniella seems more appropriate for the Songavazzo specimens. Indeed, there is a good correspondence of characters - in general shape, ornamentation and growth lines - with the Carnian forms referred by Schwardt (1992) to this genus.

\section{Acknowledgements}

I am indebted to Elio Gentili, director of the Museo Scientifico Naturalistico "Antonio Stoppani” of Venegono Inferiore (VA), who granted me access to the Stoppani Collection. I am also grateful to Giorgio Teruzzi of the Museo di Storia Naturale di Milano who searched the museum's storerooms for Stoppani's lost specimens. Paolo Guaschi (Museo di Storia Naturale dell'Università di Pavia) kindly allowed me to compare the material here described with that published by Tommasi in 1903. I also wish to thank Stefano Monari for his careful review.

\section{REFERENCES}

Bandel K., 2009 - The slit bearing nacreous Archaeogastropoda of the Triassic tropical reefs in the St. Cassian Formation with evaluation of the taxonomic value of the selenizone. Berliner paläobiologische Abhandlungen, 10: 5-47.

Benecke E.W., 1866 - Über Trias und jura in den Südalpen. GeognostichePaläontologhische Beitrage, 1: 1-204.

Chronic H., 1952 - Molluscan fauna from the Permian Kaibab Formation, Walnut Canyon, Arizona. Bulletin of the Geological Society of America, 63: 95-166.

Costa O.G., 1864 - Note geologiche e paleontologiche sui Monti Picentini nel Principato Citeriore. Reale Istituto d'Incoraggiamento alle Scienze Naturali di Napoli, ser. 2, 1: 97-112.

De Stefani C., 1880 - I fossili triasici nelle Alpi Apuane. Rendiconti del Regio Istituto Lombardo di Scienze e Lettere, ser. 2, 13: 493-497.

Garassino A., 1992 - Catalogo dei tipi del Museo Civico di Storia Naturale di Milano. I molluschi Fossili del Calcare di Esino della Collezione Stoppani. Atti della Società italiana di Scienze naturali e del Museo civico di Storia naturale di Milano, 133: 245-260.
Gatto R. \& Monari S. - Pliensbachian gastropods from venetian southern alps (Italy) and their palaeobiogeographical significance. Palaeontology, 53 (4): 771-802.

Gentili E. \& Pieroni V., 2011 - Memorie di A. Stoppani nel Seminario di Venegono Inferiore, La Scuola Cattolica, Rivista Teologica del Seminario Arcivescovile di Milano, 3: 433-458.

Haas O., 1953 - Mesozoic invertebrate faunas of Peru. American Museum Historical Bulletin, 101: 1-328.

Kittl E., 1891 - Die Gastropoden der Schichten von St. Cassian der südalpinen Trias. Teil I. Annalen des Kaiserlich-Königlichen Naturhistorischen Hofmuseum, 6: 166-262.

Kittl E., 1900 - Trias-Gastropoden des Bakonyer Waldes. In: Hölzel (Ed.) Resultate der wissenschaftlichen Erforschung des Balatonsees, part 1. Palaeontologie der Umgebung des Balatonsees, Wien-Budapest (1912) 2: 1-58.

Knight J.B., Cox L.R., Keen A.M., Smith A.G., Batten R.L., Yochelson E.L., Ludbrook N.H., Robertson R., Yonge C.M. \& Moore R.C., 1960 Mollusca-General features, Scaphopoda, Amphineura, Monoplacophora, Gastropoda- General features, Archaeogastropoda and some Caenogastropoda and Opistobranchia. In: Treatise on Invertebrate Paleontology. Part I, Mollusca 1, Moore, R.C. (ed.), Geological Society of America and University of Kansas Press, New York.

Koken E. von, 1889 - Ueber die Entwickelung der Gastropoden vom Cambrium bis zur Trias. Neues Jahrbuch für Mineralogie, Geologie und Palaeontologie, s6: 305-484.

Koninck L.G. de, 1883 - Faune du calcaire carbonifére de la Belgique, quartiéme partie. Gastéropodes. Musée Royal d'Histoire Naturelle de Belgique Annales, Série Paléontologique, 8: 1-240.

Nützel A. \& Senowbari-Daryan B., 1999 - Gastropods from the Late Triassic (Norian-Rhetian) Nayband Formation of central Iran. Beringeria 23: 93-132.

Nützel A. \& Erwin D.H., 2004 - Late Triassic (Late Norian) gastropods from the Wallowa Terrane (Idaho, USA). Palaontologische Zeitschrift, 78: 361-416.

Pieroni V., 2014 - I fossili raccolti da Antonio Stoppani conservati nel museo del Seminario Pio XI di Venegono Inferiore. (typ. Emi-Grafica).

Pieroni V., 2016 - Turriculate gastropods (Coelostylinidae) from the Esino limestone outcrop (Ladinian, Lombardy) of the Stoppani Collection housed at the Museo Civico di Storia Naturale, Milan (Italy). Natural History Sciences, Atti della Società italiana di Scienze naturali e del Museo civico di Storia naturale di Milano, 3 (2): 41-49.

Schwardt A., 1992 - Revision der Wortheniella-Gruppe (Archaeogastropoda) der Cassianer Schichten (Trias, Dolomiten). Annalen des Naturhistorischen Museum, 94A: 23-57.

Stoliczka F., 1861 - Über die Gastropoden und Acephalen der HierlatzSchichten. Sitzungsberichte der matematisch-naturwissenschaftliche Classe der kaiserlich-königlichen Akademie der Wissenschaften, 43: 157-204.

Stoppani A., 1860-65 - Géologie et paléontologie des couches à „Avicula contorta" en Lombardie, comprenant des aperçus sur l'étage infraliasien en Lombardie et en Europe en général, et deux monographies des fossiles appartenant à la zone supérieure et à la zone inférieure des couches à „Avicula contorta“ en Lombardie, une note supplémentaire et deux appendices sur l'infralias du versant N.-O. des Alpes et sur les faunes aux limites supérieures et inférieures des couches à „A. contorta“. In: Paléontologie Lombarde, ou Description des fossiles de Lombardie, publiée à l'aide de plusieurs savants. 3.e Série, (typ. Joseph Bernardoni) Milan.

Teruzzi G., 2015 - The Stoppani Collection of large Bivalves (Bivalvia, Megalodontida) from the Upper Triassic of Lombardy, Italy. Natural History Sciences, Atti della Società italiana di scienze Naturali del Museo Civico di Storia Naturale di Milano, 2 (1): 15-24.

Tichy G., 1975 - Fossilfunde aus dem Hauptdolomit (Nor, Trias) der östlichen Gailtaler Alpen (Kärnten, Österreich). Annalen des Naturhistorischen Museums in Wien, 79: 57-100.

Tommasi A., 1903 - Revisione della fauna a molluschi della dolomia principale di Lombardia. Palaeontographia Italica, 9: 93-123.

Yoo E.K., 1994 - Early Carboniferous Mollusca from the Tamworth Belt, New South Wales, Australia. Records of the Australian Museum, 46: 63-120. 